(c) American Dairy Science Association, 2004.

\title{
Short Commuunication: Effect of Dietary Protein Depletion and Repletion on Skeletal Muscle Calpastatin During Early Lactation
}

\author{
K. A. Cummins, ${ }^{1}$ S. M. Lonergan, ${ }^{2}$ and E. Huff-Lonergan ${ }^{2}$ \\ ${ }^{1}$ Dept. of Animal Sciences, Auburn University, AL 36849 \\ ${ }^{2}$ Dept. of Animal Science, lowa State University, Ames
}

\section{ABSTRACT}

Sixteen multiparous Jersey cows were assigned at calving to one of 4 dietary treatments. An $18 \%$ crude protein $(\mathrm{CP})$ diet was fed as a total mixed ration through $30 \mathrm{~d}$ in milk (DIM), and beginning at 31 DIM a 9, 12, 15 , or $18 \%$ CP diet was fed through 58 DIM (depletion). All cows were then fed the 18\% CP diet until 84 DIM (repletion). Muscle biopsies were taken under local anesthesia at 49 and 84 DIM from the semitendinosus muscle. Milk production, DMI, and milk component contents were measured. Calpain and calpastatin contents of muscle taken at biopsy were evaluated using Western blotting techniques. Milk production and milk protein content were reduced during the depletion period by decreasing dietary protein. Diet had no effect on milk fat content or DMI. During repletion, DMI was affected by dietary treatment. Western blots of muscle extracts indicated no differences in calpain content at any stage of the experiment or in calpastatin content of muscle at 49 DIM. However, at 84 DIM, calpastatin $(135 \mathrm{kDa})$ was lower or undetectable in cows fed either the 9 or $12 \%$ CP diets from 31 to 59 DIM. Bands for a $110-\mathrm{kDa}$ degradation product of calpastatin were present in some cows fed the 9,12 , and $15 \% \mathrm{CP}$ diets during the depletion period. Results indicate a change in skeletal muscle calpain/calpastatin proteolytic system during protein repletion following depletion with diets of less than $15 \% \mathrm{CP}$ during early to peak lactation in dairy cows.

(Key words: diet, calpastatin, muscle, lactation)

Abbreviation key: TEMED $=\mathrm{N}, \mathrm{N}, \mathrm{N}^{\prime}, \mathrm{N}^{\prime}$-tetramethylenediamine.

Dairy cattle are capable of mobilizing body protein, largely from skin, muscle and bone, during early lactation (Swick and Benevenga, 1977). This reserve has

Received September 9, 2003.

Accepted January 30, 2004.

Corresponding author: K. A. Cummins; e-mail: kcummins@ acesag.auburn.edu. been estimated from depletion experiments to be as large as $24 \mathrm{~kg}$ of protein (Botts et al., 1979; Huber and Kung, 1981). Dairy cows fed 16 or $19 \%$ CP diets mobilized $21 \mathrm{~kg}$ of body protein between 2 wk prepartum and 5 wk postpartum (Komaragiri and Erdman, 1997). Mobilization of body protein reserves is expected in early lactation and included in dietary nutrient requirements (NRC, 2001), although how the level of dietary CP affects skeletal muscle mobilization is not well established. Vallimont et al. (2001) observed changes in plasma amino acid concentrations consistent with mobilization of skeletal muscle in cows fed a $17.8 \% \mathrm{CP}$ diet in the immediate postpartum period, and suggested this mobilization may be for carbon skeletons needed to support glucose synthesis, independent of protein requirements.

The calpain/calpastatin system initiates turnover of myofibrillar proteins by making specific cleavages (Goll et al., 1992). Increases in calpastatin activity and resulting decreases in fractional protein degradation appear to be associated with muscle growth in cattle (Morgan et al., 1993), and callipyge lambs (Lorenzen et al., 2000). Various beta-agonists also increase muscle growth and increase calpastatin activity in cattle (Koohmaraie et al., 1991; Wheeler et al., 1992) In steers, changes in calpain and calpastatin mRNA content were proportional to changes in activity when fed a betaagonist (Parr et al., 1992),

Effects of altering dietary $\mathrm{CP}$ on muscle calpain and calpastatin content in lactating dairy cattle have not been investigated. Our hypothesis was that dietary CP restriction and refeeding would alter skeletal muscle content of calpain and calpastatin during peak lactation.

The Auburn University Institutional Animal Care and Use Committee approved all procedures. Animals were housed at the E. V. Smith Research Center Dairy Research Unit at Shorter, AL. Sixteen multiparous Jersey cows were assigned at calving to one of 4 dietary treatments in a completely randomized design. All cows were fed an $18 \%$ CP diet from calving to 30 DIM. At 31 DIM, cows were fed a $9,12,15$, or $18 \%$ CP diet until 
Table 1. Diet composition on a DM basis.

\begin{tabular}{lcccc}
\hline & \multicolumn{5}{c}{ Diet, \% CP } \\
\cline { 2 - 5 } Analysis & 9 & 12 & 15 & 18 \\
\hline Ingredients & 53.0 & 49.6 & 47. & 44.5 \\
Corn silage & 43.0 & 37.1 & 34.0 & 28.2 \\
Corn grain, cracked & 0.0 & 9.9 & 15.9 & 24.6 \\
Soybean meal, 48\% & 1.6 & 1.2 & 1.1 & 1.0 \\
Limestone, ground & 0.43 & 0.4 & 0.38 & 0.33 \\
Dicalcium phosphate & 0.46 & 0.46 & 0.50 & 0.47 \\
Salt, trace mineral & 0.30 &. &. & $\cdots$ \\
Potassium chloride & 0.50 & 0.60 & 0.36 & 0.10 \\
Potassium and magnesium & & & & \\
sulfate & 0.75 & 0.75 & 0.75 & 0.75 \\
Sodium bicarbonate & & & & \\
Analysis & 1.68 & 1.71 & 1.70 & 1.72 \\
NEL, Mcal/kg ${ }^{1}$ & 9.4 & 12.3 & 15.2 & 18.5 \\
CP, \% & 19.9 & 19.0 & 20.8 & 19.1 \\
ADF, \% & 0.83 & 0.86 & 0.91 & 1.19 \\
Ca, \% & 0.42 & 0.46 & 0.48 & 0.49 \\
P,\% & 0.87 & 0.83 & 0.99 & 0.99 \\
K, \% & 0.39 & 0.38 & 0.39 & 0.35 \\
Mg, \% & &
\end{tabular}

${ }^{1}$ Calculated from $2001 \mathrm{NRC}$, assuming DMI of $3 \mathrm{X}$ maintenance.

58 DIM (depletion period). At 59 DIM, each cow was then fed the 18\% CP diet until 84 DIM (repletion period). Diets are shown in Table 1 . The diets were fed as TMR.

Cows were milked $2 \times$ daily and housed in individual tie stalls for approximately $12 \mathrm{~h}$ per day and the remainder of the day on Bermuda grass-sodded exercise paddocks of approximately 1 ha. Milk production and DMI were measured daily. Feed samples were collected at biweekly intervals for analysis of nutrient content. Milk fat and protein were measured weekly (Southeast Dairy Lab, Inc., McDonough, GA) in composited milk samples taken from 2 sequential milkings.

Muscle biopsies were taken at 49 DIM, $19 \mathrm{~d}$ after the start of the depletion period, and at 84 DIM, after 26 $\mathrm{d}$ of repletion. Biopsies were taken from the semitendinosus muscle of alternate legs using $2 \%$ lidocain as a local anesthetic for a regional block. Samples of approximately $5 \mathrm{~g}$ wet weight were immediately frozen in liquid nitrogen upon removal.

The procedure used for sarcoplasmic muscle protein extraction was as described by Doumit et al. (1996). Ninety micrograms of protein from each sample was loaded into separate wells of a $10 \mathrm{~cm} \times 12 \mathrm{~cm} \times 1.5 \mathrm{~mm}$ Hoefer SE 260B Mighty Small II (Pharmacia Biotech; San Francisco, CA) 15\% (for calpastatin) and 10\% (for $\mu$-calpain) acrylamide separating gel (acrylamide/bis [100:1 acrylamide: bisacrylamide]), $0.375 M$ Tris- $\mathrm{HCl}$, $\mathrm{pH} 8.8,0.1 \%$ SDS, $0.05 \%$ ammonium persulfate, and $0.05 \% \mathrm{~N}, \mathrm{~N}, \mathrm{~N}^{\prime}, \mathrm{N}^{\prime}$-Tetramethylenediamine (TEMED). The separating gels had a 5\% acrylamide stacking gel (5\% acrylamide/bis [100:1 acrylamide: bisacrylamide],
$0.125 M$ Tris-HCl, $\mathrm{pH} 6.8,0.1 \%$ SDS, $0.125 \%$ TEMED, and $0.075 \%$ ammonium persulfate). The composition of the running buffer used was $25 \mathrm{~m} M$ Tris, $192 \mathrm{mM}$ glycine, and $0.1 \%$ SDS, $\mathrm{pH}$ 8.3. At completion, the proteins on the gel were transferred immediately to Westran PVDF (polyvinylidene fluoride) membranes (Schleicher \& Schuell, Inc.; Keene, NH). Gels were transferred for $90 \mathrm{~min}$ at $90 \mathrm{~V}$ at $4^{\circ} \mathrm{C}$ in a TE 22 Transphor Electrophoresis Unit (Hoefer Scientific Instruments; San Francisco, CA). Calpastatin was detected using a mouse anti-calpastatin antibody as described by Lonergan et al. (2001) $\mu$-Calpain was detected with a mouse anti- $\mu$-calpain (cat. \# RDI-Ucalpain; Research Diagnostics Inc., Flanders, NJ) diluted 1:1000 in PBS-Tween (80 $\mathrm{m} M \mathrm{Na}_{2} \mathrm{HPO}_{4}, 20 \mathrm{mM}$ $\mathrm{NaH}_{2} \mathrm{PO}_{4}, 100 \mathrm{mM} \mathrm{NaCl}$, and $0.1 \%$ polyoxyethylene 20-sorbitan monolaurate [Tween 20]). Membranes were incubated for $1 \mathrm{~h}$ at room temperature in secondary antibody, goat-anti-mouse IgG conjugated with horseradish peroxidase, (cat. \# A2554, Sigma; St. Louis, MO) diluted 1:5,000 in PBS-Tween with $1 \%$ nonfat dry milk). Bands were visualized using ECL Western Blotting reagents (Amersham Life Science, Arlington Heights, IL) by exposure to film (Kodak BioMax Light-1 Film, $13 \times 18 \mathrm{~cm}$, Kodak No. 8689358) as directed by the manufacturer.

Statistical analysis for milk production, DMI, and milk components was analysis of variance for a completely randomized design with repeated measures. Analysis was done using the PROC GLM procedure of SAS (SAS Institute, 1999), with treatment (diet sequence), period (depletion or repletion) treatment $\times$ period, and cow within treatment in the model. Cow within treatment was used to test the main effects of diet and period.

Mean milk production, DMI, and milk protein contents for the depletion and repletion periods are shown in Table 2. Milk production was lower in cows fed low CP during the depletion period $(P<0.05)$, but not during the repletion period. Cows fed lower dietary CP consumed more DM during the repletion period $(P<0.05)$. There was a treatment $\times$ period interaction for both milk production and DMI $(P<0.05)$. Milk protein content was reduced in cows fed lower CP diets $(P<0.05)$. Milk fat content was not altered by period or treatment $(P>0.1)$.

Western blots for $\mu$-calpain (data not shown) indicated no apparent differences at any time during the study. All Western blots showed one band of approximately $80 \mathrm{kDa}$. Calpastatin did not vary with dietary treatment at 49 DIM, with uniform bands observed for both a 135 and $67 \mathrm{kDa}$ form.

Two Western blots of muscle calpastatin at 84 DIM for 4 cows, one each for the 4 dietary treatments on 
Table 2. Milk production, DMI, and milk protein content during depletion (31 to 58 DIM) and repletion (59 to $84 \mathrm{DIM}$ ) in cows fed varying dietary CP during the depletion period.

\begin{tabular}{llllllll}
\hline & & \multicolumn{3}{c}{ Depletion period dietary CP content, $\%$} & & \multicolumn{2}{c}{ Pooled } \\
\cline { 3 - 5 } \cline { 3 - 5 } & Period & $9 \%$ & $12 \%$ & $15 \%$ & & $18 \%$ & SEM \\
\hline DMI, kg/d & Depletion & 13.9 & 14.5 & 14.5 & & 14.9 & 1.2 \\
& Repletion & $16.6^{\mathrm{b}}$ & $13.6^{\mathrm{a}}$ & $15.7^{\mathrm{ab}}$ & & $13.5^{\mathrm{a}}$ & \\
Milk, kg/d & Depletion & $25.7^{\mathrm{a}}$ & $28.4^{\mathrm{b}}$ & $27.5^{\mathrm{b}}$ & & $27.9^{\mathrm{b}}$ & 1.3 \\
& Repletion & 26.8 & 30.3 & 28.2 & & 30.2 & \\
Milk protein, \% & Depletion & $3.20^{\mathrm{a}}$ & $3.27^{\mathrm{ab}}$ & $3.34^{\mathrm{ab}}$ & & $3.41^{\mathrm{b}}$ & 0.03 \\
& Repletion & $3.32^{\mathrm{a}}$ & $3.36^{\mathrm{a}}$ & $3.48^{\mathrm{ab}}$ & & $3.66^{\mathrm{b}}$ & \\
Milk fat, \% & Depletion & 4.4 & 3.9 & 4.2 & & 3.9 & 0.05 \\
& Repletion & 4.1 & 4.4 & 3.7 & & 4.1 & \\
\hline
\end{tabular}

${ }^{\mathrm{a}, \mathrm{b}}$ Values within each period without a common superscript vary by dietary treatment, $P<0.05$.

${ }^{1}$ Cows fed the indicated dietary CP content from 31 to 58 DIM (depletion period). All cows were fed an 18\% CP diet from 59 to 84 DIM (repletion).

each blot, are shown in Figure 1. All blots for calpastatin for samples taken during the repletion period (84 DIM) showed the same pattern. A $135-\mathrm{kDa}$ band was observed at 84 DIM only for cows fed the 15 and $18 \% \mathrm{CP}$ diets from 31 to 58 DIM. Cows fed the 9 and $12 \% \mathrm{CP}$ diets during this period did not show the $135-\mathrm{kDa}$ band. A band for a $67-\mathrm{kDa}$ form was observed in all cows.

It was hypothesized that changes in the calpain/calpastatin system would occur during the depletion period in dairy cows, but none was observed. Alterations in muscle content of the $135-\mathrm{kDa}$ form of calpastatin were noted only during the repletion period and only in those animals fed 9 or $12 \% \mathrm{CP}$ diets during the depletion period. Increases in muscle calpastatin have been noted during growth in callipyge lambs (Lorenzen et al., 2000), and in lambs fed a beta-agonist (Speck et al., 1993). Dietary restriction increased calpastatin content of muscle in lambs only when a beta-agonist was fed (Higgins et al., 1988). Growing cattle have shown increased calpastatin content in muscle and decreased fractional breakdown rates (Morgan et al., 1993). In this study with lactating dairy cows, calpastatin decreased during repletion while feeding of an $18 \% \mathrm{CP}$ diet only in those animals fed the 9 and $12 \% \mathrm{CP}$ diets during the depletion phase, the cattle most likely to be undergoing

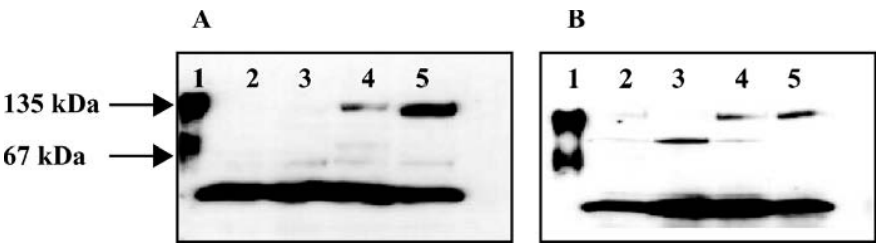

Figure 1. Western blots of muscle tissue extracts from muscle biopsies taken at 84 DIM during the repletion period when all cows were fed the $18 \% \mathrm{CP}$ diet. Blots are of four different cows each (A and $\mathrm{B}$ are replicates). Lane 1 is purified muscle calpastatin $(135 \mathrm{kDa})$. Lane 2, 3, 4, and 5 are from cows fed the $9,12,15$ and $18 \%$ CP diets, respectively, during the repletion period ( 31 to $58 \mathrm{DIM}$ ). muscle growth. The $67-\mathrm{kDa}$ form of calpastatin observed is either a degradation product of muscle calpastatin or erythrocyte calpastatin (Takano et al., 1991).

Regulation of muscle breakdown and growth during a period of dietary repletion appears to differ in dairy cows from the mechanism regulating growth in young cattle. Calpastatin was altered by periods of protein depletion and repletion but in an opposite manner from that usually observed in growing cattle, decreasing in cattle previously fed lower dietary $\mathrm{CP}$ and which would be undergoing muscle protein repletion when fed high CP diets. Dairy cows are mature animals, and, while synthesizing large quantities of protein daily, it is exported in the milk. These factors may explain the different response observed compared to growing cattle.

\section{REFERENCES}

Botts, R. L., R. M. Hemken, and L. S. Bull. 1979. Protein reserves in the lactating dairy cow. J. Dairy Sci. 62:433-440.

Doumit, M. E., S. M. Lonergan, J. R. Arbona, J. Killefer, and M. Koohmaraie. 1996. Development of an enzyme-linked immunosorbent assay (ELISA) for quantification of skeletal muscle calpastatin. J. Anim. Sci. 74:2679-2686.

Goll, D. E., V. T. Thompson, R. G. Taylor, and J. A. Christiansen. 1992. Role of the calpain system in muscle growth. Biochimie 74:225-237.

Higgins, J. A., Y. V. Lasslett, R. G. Bardsley, and P. J. Buttery. 1988. The relationship between dietary restriction or clenbuterol (a selective $\beta$-agonist) treatment on muscle growth and calpain proteinase (E. C. 3.4.22.17) and calpastatin activities in lambs. Br. J. Nutr. 60:645-652.

Huber, J. T., and L. Kung, Jr. 1981. Protein and nonprotein nitrogen utilization in dairy cattle. J. Dairy Sci. 64:1170-1195.

Koohmaraie, M., S. D. Shakelford, N. E. Muggli-Cockett, and R. T. Stone. 1991. Effect of the $\beta$-adrenergic agonist $\mathrm{L}_{844,969}$ on muscle growth, endogenous proteinase activity, and post-mortem proteolysis in wether lambs. J. Anim. Sci. 69:4823-4835.

Komaragiri, M. V., and R. A. Erdman. 1997. Factors affecting body tissue mobilization in early lactation dairy cows. 1. Effect of dietary protein on mobilization of body fat and protein. J. Dairy Sci. 80:929-937.

Lonergan, S. M., E. Huff-Lonergan, B. R. Wiegand, and L. A. KrieseAnderson. 2001. Postmortem proteolysis and tenderization of top loin steaks from Brangus cattle. J. Muscle Foods 12:121-136. 
Lorenzen, C. L., M. Koohmaraie, S. D. Shackelford, F. Johoor, H. C. Freetly, T. L. Wheeler, J. W. Savell, and M. L. Fiorotto. 2000. Protein kinetics in callipyge lambs. J. Anim. Sci. 78:78-87.

Morgan, J. B., T. L. Wheeler, M. Koohmaraie, J. D. Crouse, and J. W. Savell. 1993. Effect of castration on myofibrillar protein turnover, endogenous proteinase activities, and muscle growth in bovine skeletal muscle. J. Anim. Sci. 71:408-414.

National Research Council. 2001. Nutritional Requirements of Dairy Cattle. 7th rev. ed. National Academy of Science, Washington, DC.

Parr, T., R. G. Bardsley, R. S. Gilmour, and P. J. Buttery. 1992. Changes in calpain and calpastatin mRNA induced by $\beta$-adrenergic stimulation of bovine skeletal muscle. Eur. J. Biochem. 208:333-339.

SAS Users Guide: Statistics, Version 6 Edition. 1991. SAS Institute, Inc. Cary, NC.
Speck, P. A., K. M. Collingwood, R. G. Bardsley, G. A. Tucker, R. S. Gilmom, and R. J. Buttery. Transient changes in growth and calpain and calpastatin expression in ovine skeletal muscle after short-term dietary inclusion of cimaterol. Biochemie 75:917-923.

Swick, R. W., and N. J. Benevenga. 1977. Labile protein reserves and protein turnover. J. Dairy Sci. 60:505-515.

Takano, E., M. Ueda, W. S. Tsuneka, T. Murakami, M. Maki, M. Hatanaka, and T. Murachi. 1991. Molecular diversity of erythrocyte calpastatin. Biomen. Biocim. Acta 50:517-521.

Vallimont, J. E., G. A. Varga, A. Ariell, T. W. Cassidy, and K. A. Cummins. 2001. Effects of prepartum somatotropin and monensin on metabolism and production of periparturient Holstein dairy cows. J. Dairy Sci. 84:2607-2621.

Wheeler, T. L. and M. Koohmaraie. 1992. Effect of the $\beta$-adrenergic agonist $\mathrm{L}_{644.969}$ on muscle protein turnover, endogenous proteinase activities, and meat tenderness in steers. J. Anim. Sci. 70:3035-3043. 